\title{
OBSERVATIONS ON THE FORMATION OF WHEALS
}

\author{
V. The Effects of Variation of the $\mathrm{CO}_{2}$ Combining Power of \\ the Blood on Histamine Wheals
}

By F. S. McCONNELL, W. K. WEAVER AND H. L. ALEXANDER

(From the Department of Medicine, Washington University Medical School and the Barnard Free Skin and Cancer Hospital, St. Louis)

(Received for publication August 14, 1931)

In a previous paper (1) it was shown that calcium salts in very high dilutions only are able to augment the size of histamine wheals. The following experiments were designed to show the effects of changes in $\mathrm{CO}_{2}$ combining power in the blood of dogs after the administration of acid and alkaline salts, on the size of histamine wheals. The method employed was as follows:

Control tests were made intradermally with the following solutions: $0.02 \mathrm{cc}$. of histamine acid phosphate; $0.02 \mathrm{cc}$. of a 1 to 100,000 dilution of calcium sulphate, and $0.02 \mathrm{cc}$. of a 1 to 10 dilution of active skin extract. Each of the three solutions were made up to contain the same concentration of histamine acid phosphate. The resulting wheals were measured 15 minutes after intradermal injections, and were recorded in square centimeters. Both calcium and skin extract were used in these experiments to serve as a check on each other, since it has been shown that the augmenting power of skin extract on histamine wheals is due to its calcium content:"

Blood was then drawn under oil from the heart. The serum was separated and exposed to a $\mathrm{CO}_{2}$ (5 per cent) $\mathrm{O}_{2}$ (95 per cent) mixture, and the $\mathrm{CO}_{2}$ combining power determined according to the method of Van Slyke and Neill (2). Ammonium chloride dissolved in 40 times its weight in water to prevent vomiting was administered by stomach tube. Six grams of the salt were usually sufficient to produce a distinct lowering of the $\mathrm{CO}_{2}$ combining power of the blood in a dog of 5 kilos. At intervals of 15 to 30 minutes after the ammonium chloride had been given, intradermal tests, with the same solutions as above, were repeated. As soon as a variation in the size of wheals when compared to the control tests was noted, blood was drawn again and the $\mathrm{CO}_{2}$ combining power of the serum determined as before. If the drop in $\mathrm{CO}_{2}$ was pronounced, the intradermal tests were repeated again 18 hours later, and a final $\mathrm{CO}_{2}$ estimation made. No anesthetic was used.

When the $\mathrm{CO}_{2}$ combining power of the blood was lowered, the sizes of the wheals were always smaller than the controls, although the amount 
of total calcium in the blood serum remained unchanged. The amount of lowering of the $\mathrm{CO}_{2}$ combining power varied considerably, but with a drop of only 12 volumes per cent, the sizes of the wheals at times were markedly reduced when compared with the control tests. As the $\mathrm{CO}_{2}$ combining power gradually returned to normal, the wheals again became larger. For example, in one experiment, a histamine wheal measured 0.7 sq. $\mathrm{cm}$. when the $\mathrm{CO}_{2}$ combining power of the blood was 60 volumes per cent. After the administration of ammonium chloride, the $\mathrm{CO}_{2}$ dropped to 45 volumes per cent. A histamine wheal then measured but 0.4 sq. cm. Finally, as the $\mathrm{CO}_{2}$ rose to about its previous level, a histamine wheal again measured approximately $0.7 \mathrm{sq} . \mathrm{cm}$. In these experiments

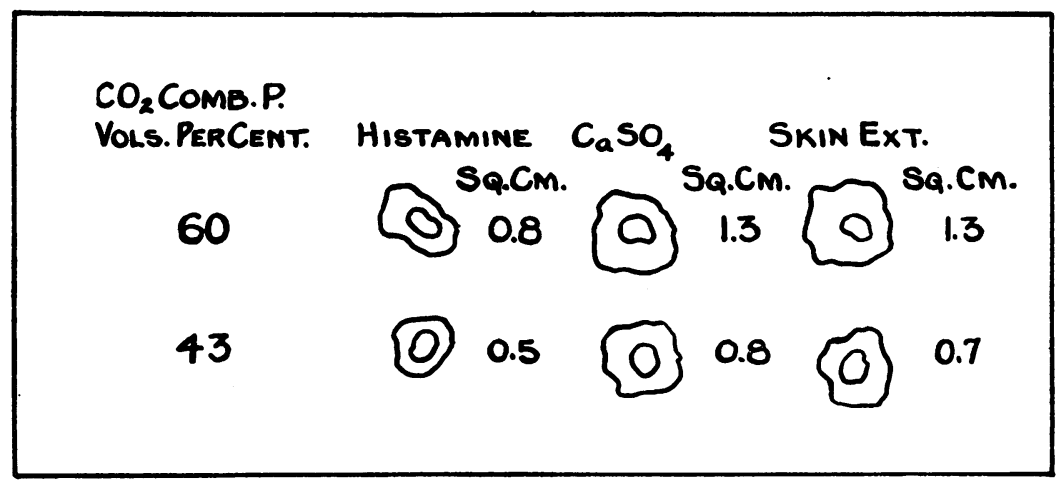

Fig. I. The Effect of a Lowered $\mathrm{CO}_{2}$ Combining Power of the Blood ON THE Size OF Wheals

Histamine $=$ Histamine acid phosphate 1 to 2,000 dilution.

$\mathrm{CaSO}_{4}=1$ to 100,000 dilution made up to contain histamine acid phosphate 1 to 2,000 .

Skin extract $=1$ to 10 dilution made up to contain histamine acid phosphate 1 to 2,000 .

Figures $=$ Increase in area of wheals measured in square centimeters fifteen minutes after injection.

histamine acid phosphate was used in high concentrations so that the resulting wheals were large. This was done in order to measure variations in size more accurately. In preliminary experiments the $\mathrm{pH}$ of the blood was found to be lowered after the administration of acid salts associated with a diminution in size of wheals. The $\mathrm{pH}$ was measured according to the method of Hastings and Sendroy (3).

The same method was followed in experiments to determine the size of wheals when the $\mathrm{CO}_{2}$ combining power of the blood was elevated. A distinct rise in $\mathrm{CO}_{2}$ was usually obtained with $200 \mathrm{cc}$. of a six per cent solution of sodium bicarbonate administered by stomach tube.

When $\mathrm{CO}_{2}$ combining power was elevated, there was always an associated increase in the sizes of wheals as compared to the controls. 
Moreover, as the $\mathrm{CO}_{2}$ resumed its original level, the wheals again became smaller. For example, a histamine wheal measured $1.0 \mathrm{cc}$. when the $\mathrm{CO}_{2}$ combining power was 60 volumes per cent. Forty-five minutes after sodium bicarbonate had been given, the $\mathrm{CO}_{2}$ value rose to 78 . The total serum calcium remained unchanged. At this time, a histamine wheal measured $1.6 \mathrm{~cm}$., about 60 per cent larger than the control wheal. The following day, both the $\mathrm{CO}_{2}$ combining power and the size of the histamine wheal had assumed their original values. In preliminary experiments, the $\mathrm{pH}$ of the blood was found to be elevated after the administration of alkaline salts associated with an increase in the size of wheals.

$\mathrm{CO}_{2}$ COMB.P.

Vols.PerCent. Histamine $\mathrm{CaSO}_{4}$ Skin Ext.

57
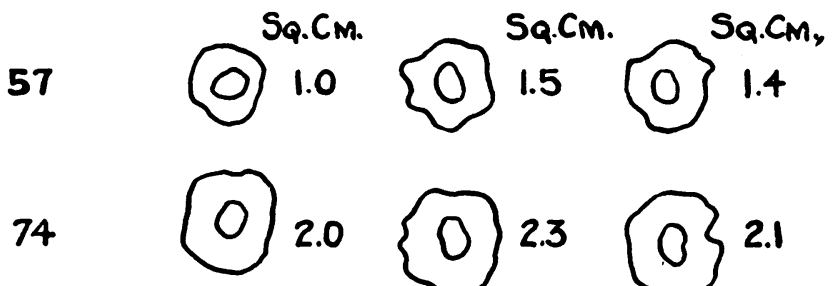

2.0

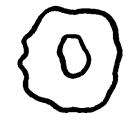

2.3

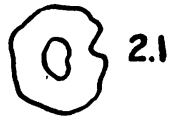

Fig. II. The Effect of an Elevated $\mathrm{CO}_{2}$ Combining Power of the Blood on the Size of Wheals

Histamine $=$ Histamine acid phosphate 1 to 2,000 dilution.

$\mathrm{CaSO}_{4}=1$ to 100,000 dilution made up to contain histamine acid phosphate 1 to 2,000 .

Skin extract $=1$ to 10 dilution made up to contain histamine acid phosphate 1 to 2,000 .

Figures $=$ Increase in area of wheals measured in square centimeters fifteen minutes after injection.

The following protocol shows the results of two experiments, one with a lowered and one with a raised $\mathrm{CO}_{2}$ combining power. These were selected as typical experiments from a series of 19 . (Table I.)

It is known that citrates markedly influence diffusible and ionic calcium in complex solutions such as blood (4). This (5) was suggested in previous experiments (1). To a 1 to 100,000 solution of calcium sulphate, containing four per cent sodium citrate, was added histamine acid phosphate, in an amount sufficient to make a concentration of 1 to 10,000 . The mixture was adjusted to a $\mathrm{pH}$ of 7.2. When this solution was injected intradermally into a normal dog, calcium failed to augment the 
TABLE I

The effects of changes in $\mathrm{CO}_{2}$ combining power of the blood on the sizes of wheals

\begin{tabular}{|c|c|c|c|c|c|c|c|}
\hline $\begin{array}{l}\text { Date, dog number } \\
\text { and weight }\end{array}$ & Time & $\begin{array}{c}\mathrm{CO}_{2} \\
\text { com- } \\
\text { bining } \\
\text { power }\end{array}$ & $\begin{array}{l}\text { Serum } \\
\text { cal- } \\
\text { cium }\end{array}$ & $\begin{array}{l}\text { Hista- } \\
\text { mine }\end{array}$ & CasO، & $\begin{array}{l}\text { Skin } \\
\text { ex- } \\
\text { tract }\end{array}$ & Comment \\
\hline \multirow{3}{*}{$\begin{array}{l}\text { March } 18,1931 . \\
\text { Dog } 5 . \quad \text { Weight } \\
\text { approximately } 5 \\
\text { kilos }\end{array}$} & a.m. & $\begin{array}{c}\text { vol- } \\
\text { umes } \\
\text { per } \\
\text { cent }\end{array}$ & $\begin{array}{l}\text { per } \\
100 \text { cc }\end{array}$ & sq. $\mathrm{cm}$. & sq. $\mathrm{cm} . \mid$ & & \multirow{3}{*}{$\begin{array}{l}6.0 \text { grams } \mathrm{NH}_{4} \mathrm{Cl} \text { in } 200 \mathrm{cc} \\
\text { water given in stomach }\end{array}$} \\
\hline & $\begin{array}{l}10: 00 \\
10: 15\end{array}$ & 60 & 10.3 & 0.8 & 1.3 & 1.1 & \\
\hline & $\begin{array}{l}10: 30 \\
10: 45\end{array}$ & 47 & 10.2 & $\begin{array}{l}0.9 \\
0.5\end{array}$ & $\begin{array}{l}1.2 \\
0.6\end{array}$ & $\begin{array}{l}1.0 \\
0.7\end{array}$ & \\
\hline \multirow{2}{*}{$\begin{array}{l}\text { April 5, } 1931 . \\
\text { Dog 9. Weight } \\
\text { approximately } 7 \\
\text { kilos }\end{array}$} & $\begin{array}{l}11: 00 \\
11: 15\end{array}$ & 59 & 9.8 & 1.0 & 1.4 & 1.3 & \multirow[t]{2}{*}{$\begin{array}{l}6.0 \text { grams } \mathrm{NaHCO}_{3} \text { in } 200 \\
\text { cc. water given in stomach }\end{array}$} \\
\hline & $\begin{array}{l}11: 30 \\
11: 45\end{array}$ & 78 & 10.0 & $\begin{array}{l}1.2 \\
1.6\end{array}$ & $\begin{array}{l}1.4 \\
1.8\end{array}$ & $\begin{array}{l}1.3 \\
1.9\end{array}$ & \\
\hline
\end{tabular}

Histamine $=$ Histamine acid phosphate 1 to 2,000 dilution. 2,000 .

$\mathrm{CaSO}_{4}=1$ to 100,000 dilution made up to contain histamine acid phosphate 1 to 2,000 .

Skin extract $=1$ to 10 dilution made up to contain histamine acid phosphate 1 to

Figures $=$ Increase in area of wheals measured in square centimeters fifteen minutes after injection.

histamine wheal. Moreover, a histamine solution containing four per cent sodium citrate and no calcium induced a wheal that was smaller than that given by histamine alone.

The effect on wheal formation of sodium citrate administered to a dog, was studied. One hundred cc. of a five per cent sodium citrate solution was given by stomach tube. The same procedure was followed as that recorded in the experiments above. It was found that sodium citrate invariably caused a rise in the $\mathrm{CO}_{2}$ combining power. Despite this, in no instance did the size of wheals appreciably increase. As a rule, they remained about the same size as the controls. Occasionally there was a decrease. In one $\mathrm{dog}$ on which the experiment was done repeatedly, there was a marked reduction (about 40 per cent) in the size of wheals after sodium citrate had been given, although the $\mathrm{CO}_{2}$ combining power of the blood rose 20 volumes per cent. The total serum calcium was not appreciably affected.

That neither the sodium nor the chloride ion of the salts administered was responsible for the changes noted, had been determined in previous experiments wherein glucose was substituted for the sodium chloride used to produce isotonicity in the solutions injected. Under these circumstances, the wheal-forming activity of the solutions remained unchanged. 


\section{SUMMARY}

1. The ingestion of acid in the form of ammonium chloride diminishes the sizes of histamine wheals as well as those formed from a combination of histamine with calcium sulphate and from histamine with skin extract. Ingestion of sodium bicarbonate, on the other hand, increases the size of such wheals.

2. The ingestion of sodium citrate caused an alkalinization which was not accompanied by an increase in size of histamine wheals. At times the wheals were markedly reduced in size.

While it is tempting to consider that these phenomena may be explained on the basis of changes in calcium ion concentration, the conditions actually existing in the tissues are too little known to justify this conclusion.

Further experiments are being conducted on the behavior of the localized edemas of allergy under conditions that influence wheal formation.

\section{BIBLIOGRAPHY}

1. Weaver, W. K., Alexander, H. L., and McConnell, F. S., J. Clin. Invest., 1932, xi, 195. Observations on the Formation of Wheals. IV. The Influence of Calcium Concentrations on Histamine Wheals.

2. Van Slyke, D. D., and Neill, J. M., J. Biol. Chem., 1924, 1xi, 523. The Determination of Gases in Blood and Other Solutions by Vacuum Extraction and Manometric Measurements.

3. Hastings, A. B., and Sendroy, J., J. Biol. Chem., 1924, lxi, 695. Studies of Acidosis. XX. The Colorimetric Determination of Blood pH at Body Temperatures without Buffer Standards.

4. Stewart, C. P., and Percival, G. H., Biochem. J., 1928, xxii, 548, 559. Studies in Calcium Metabolism. II. The Calcium Content of Corpuscles, Plasma and Serum. III. Calcium and the Coagulation of Blood.

5. Shelling, D. H., and Maslow, H. L., J. Biol. Chem., 1928, lxxviii, 661. The Effect of Sodium Citrate, Acetate, and Lactate on the Ultrafiltrability of Serum Calcium. 